\title{
Determination of selected micro and macronutrients in sugarcane growing soils at Kakamega North District, Kenya
}

\author{
Preston Akenga ${ }^{1}$, Ali Salim ${ }^{1 *}$, Anam Onditi ${ }^{1}$, Amir Yusuf ${ }^{2}$, \\ Walyambillah Waudo ${ }^{1}$ \\ 1Department of Chemistry, Jomo Kenyatta University of Agriculture and Technology (JKUAT), P. O Box 62000 \\ - 0200 CITY SQUARE, Nairobi, Kenya \\ ${ }^{2}$ Department of Chemistry, University of Nairobi, P.O Box 30197 - 00100 Nairobi, Kenya
}

\begin{abstract}
Kakamega North district is situated in Kakamega County in the western region of the Republic of Kenya. It is a major sugarcane producing area. The soils in the area were analyzed for selected macro and micronutrients. Macronutrients analyzed included potassium, sodium, calcium, phosphates and nitrates while the micronutrients analyzed were copper, iron and zinc. The techniques employed were Flame Atomic Absorption Spectrometry, Flame Emission Spectrometry and UV/Visible Spectrophotometry. The soil pH measurement was also taken. The average levels obtained in $\mathrm{mg} / \mathrm{kg}$ for potassium, sodium, calcium, nitrates and phosphates were 110, 240.8, 540, 71 and 100 respectively. Recommended nutrient range levels in $\mathrm{mg} / \mathrm{kg}$ as per Kenya Agricultural Research Institute (KARI) are: potassium $1-100 \mathrm{mg} / \mathrm{kg}$, sodium 20-300mg/kg, calcium 2$400 \mathrm{mg} / \mathrm{kg}$, nitrates above $42 \mathrm{mg} / \mathrm{kg}$ and finally for phosphates $2000-5000 \mathrm{mg} / \mathrm{kg}$. The results indicate generally that macronutrient levels of phosphates and nitrates were low and below the required minimum required levels for normal plant. Micronutrients were within the limits for normal plant growth. The average soil pH was 5.48 which is acidic and within the limits for normal plant growth.
\end{abstract}

Keywords: Soil, macronutrients, micronutrients, fertility, sugarcane

\section{Introduction}

Kakamega North District in Western Province is about $30 \mathrm{~km}$ from the western capital Kakamega town. This is a sugarcane growing region which is mostly done by small scale farmers. The crop was introduced in the region by the colonialists in the 1940's. The sugar sub-sector plays an important role in the Kenya's economy. The sub-sector generates an estimated 12 billion Kenya Shillings annually, providing approximately 500,000 jobs. It also supports livelihood of about six million people.

There are currently, about 163,000 farmers involved in cane production. It is a foreign exchange earner and if produced sufficiently can save on import expenditure ${ }^{1}$. Presently the crop yield has been decreasing despite improvement on cane varieties. This could partially be attributed to declining soil fertility, ineffective weed control strategies, intermittent moisture stress and continuous sugarcane monoculture. It is with this background in mind that the study was under taken. In general, most plants grow by absorbing nutrients from the soil. Their ability to do this depends on the nature of the soil. The makeup of a soil (soil texture) and its $\mathrm{pH}$ determine the extent to which nutrients are available to plants. Soil properties that are important to the growth of plants include soil fertility and soil stability. Soil fertility is the amount of plant nutrients available in soil while soil stability is the ability of soil to resist erosion mostly determined by soil texture, structure consistency and hardness of layers ${ }^{2}$.

Mineral nutrients are divided into two types: macronutrients and micronutrients. Macronutrients are further divided into primary and secondary. Primary nutrients are used in large quantities by plants and they include nitrogen, phosphorus and potassium. Secondary nutrients include calcium, magnesium and sulfur. Micronutrients are needed in very small amounts and they include boron, copper, iron, manganese and zinc ${ }^{3}$. Having the right amount of nutrients is essential for normal plant growth and reproduction. As nutrient ions are removed from soil solution by plant absorption they are replenished from several sources. Seldom is the rate of renewal for all essential elements from untreated soil fast enough to achieve maximum crop production. To augment this removal fertilizers are usually applied ${ }^{4}$. Soil $\mathrm{pH}$ is one of the most important soil properties that affect the availability of nutrients and hence it was also measured. In general macronutrients tend to be less available in soils with low $\mathrm{pH}$ while micronutrients tend to be less available in soils with high $\mathrm{pH}^{5}$.

In this study, seven nutrients were analyzed. The four macronutrients analyzed include potassium, calcium nitrates and phosphates and three micronutrients zinc, iron and copper. 


\section{Macronutrients}

\section{Role Of Nutrients To Plants}

Potassium has a number of structural functions in plants and animals. It keeps the cell cytoplasm levels relatively constant, assists in protein synthesis and energy metabolism.

Potassium is absorbed by plants in larger amounts than any other mineral element except nitrogen and in some cases calcium.

Calcium which is an essential part of plant cell wall structure, provides for normal transport and retention of other elements as well as the strength in the plant. It also counteracts the effects of alkali salts and organic acids within a plant ${ }^{6}$.

Phosphorous occurs in soil almost entirely as phosphates $\left(\mathrm{PO}^{-3}{ }_{4}\right)$ and resembles nitrogen in that both inorganic and organic forms are of major significance in agricultural soil. Agricultural soils usually cannot meet demand for phosphate and application of fertilizer is essential. Phosphorus is an essential part of the process of photosynthesis. It is involved in the formation of all oils, sugars and starches. It helps with the transformation of solar energy into chemical energy; proper plant maturation; withstanding stress, affects rapid growth and encourages blooming and root growth ${ }^{2}$.

Nitrogen in the inorganic form of $\left(\mathrm{NO}_{3}^{-}\right)$is important because it is the one utilized by plants. Crop demand for this nutrient is high thus the need to apply fertilizer. Nitrogen is a part of all living cells and is a necessary part of all proteins, enzymes and metabolic processes involved in the synthesis and transfer of energy. Nitrogen is a part of chlorophyll, the green pigment of the plant that is responsible for photosynthesis. It assists plants with rapid growth, increasing seed and fruit production and improving the quality of leaf and forage crops $^{6}$.

Macronutrients are essential to plant growth but utilized in trace quantities. Their major role is as activators in numerous enzyme systems. Micronutrients are toxic when they are in very high levels thus they become a threat to human and animals life and cause stunted growth and poor yield in plants ${ }^{3}$.

Copper is an essential micronutrient for plants and animals. It is involved in many enzyme systems of plants and animals. Iron is an essential minor nutrient for plants and animals. It is involved in chlorophyll synthesis in chloroplast. Zinc is essential for the transformation of carbohydrates. It regulates consumption of sugars. It is part of the enzyme systems which regulate plant growth ${ }^{6}$.

\section{Equipment and Instruments}

\section{Methodology}

UV/VIS Spectrophotometer- Pharmacia Biotech (NOVASPEC 11), Atomic Absorption SpectrometerBuck 210 VGP, Flame photometer- Giba Corning Flame Analyser 04, pH meter- Hannah instruments 211, Shaker- Taiyo Reciproshaker SR-1, Conical flasks, Volumetric flask, Glass cylinders.

\section{Sampling}

Variation in slope, soil color, soil texture, crop growth and management was taken into account and separate sets of composite samples were collected from each location at different farms. Since sugarcane is a deep rooted crop, soil samples were collected at a depth of $20-25 \mathrm{~cm}$.

\section{Sampling Procedure}

During sample collection, dead furrow, old manure, wet spots, areas under or near trees were avoided. Surface litter was scrapped off often using a spade and a hoe, a V- shaped hole of between $20-25 \mathrm{~cm}$ deep dug and a $1.5 \mathrm{~cm}$ thick soil from top to bottom of the hole collected and placed in a clean bucket. Ten samples of this kind were collected randomly in a single location. The composite samples from the ten spots in each location were thoroughly mixed in a bucket.

\section{Reduction of sample bulk}

This was done by quartering the soil sample collected to about $500 \mathrm{~g}$. Quartering was done by dividing the mixed soil in four equal parts then discarding two parts. The two quarters were remixed and again divided into four parts discarding two then process was repeated until the required small amount was obtained. Stones, large roots and other coarse fragments were removed by passing the dry material through a $2 \mathrm{~mm}$ sieve. The soil was lightly crushed in between sheets of polythene ${ }^{7}$.

Drying

Drying was done under moderate temperatures under shade where air circulation was possible. 


\section{Sample Storage and Transportation}

The soil samples were placed in paper bags, labeled A, B, C, D and E and had a slip out containing the following information: name of the location from which the sample was collected; depth of sampling, number of samples mixed to get representative sample, soil type ( coarse or heavy), crop growth (good/ poor/ average). The sampling record also included human influence such as grazing, fertilizer applied, and vegetation burning ${ }^{7}$.

\section{Analysis of soil samples}

Preparation of soil samples for potassium, sodium and calcium analysis

\section{Reagents:}

Extracting Solution: $0.7 \mathrm{ml}$ of concentrated $\mathrm{H}_{2} \mathrm{SO}_{4}$ was mixed with $8.6 \mathrm{ml}$ of $\mathrm{HCl}$ then $800 \mathrm{ml}$ of distilled water added in $1000 \mathrm{~mL}$ volumetric flask. The solution was topped up to the mark with distilled water. $10 \mathrm{~g}$ of the soil sample was placed in plastic bottles and $50 \mathrm{ml}$ of the extracting solution added then taken to a reciprocating shaker where it was shaken for one hour. The solution was filtered by Whatman No. 42 filter paper and the filtrate stored.

\section{Determination of Potassium}

\section{Determination Of Macronutrients}

Stock solution of potassium standard $(1000 \mathrm{mg} / \mathrm{l})$ was prepared by dissolving $1.9068 \mathrm{~g}$ of dry $\mathrm{KCl}$ in distilled water and volume made up to $1000 \mathrm{ml}$. The stock solution was diluted to produce working standards of concentration range $1-100 \mathrm{mg} / \mathrm{l}$. Each working standard was run in the emission spectrometer and the intensity for each standard was recorded. The calibration curve was constructed to determine the concentration of potassium in the soil sample. The blanks were also determined in the same way and subtraction done where necessary.

$$
\text { Calculations: } \mathrm{K}, \mathrm{Na}, \mathrm{Ca}(\mathrm{mg} / \mathrm{Kg})=\frac{(\mathrm{a}-\mathrm{b}) \times \mathrm{V} \times \mathrm{f} \times 1000}{1000 \times \mathrm{w}}
$$

Where: $\mathrm{a}=$ concentration of $\mathrm{K}, \mathrm{Ca}, \mathrm{Na}$ in the sample extract

$\mathrm{b}=$ concentration of element in the blank extract

P Akeng'a et al

$$
\begin{aligned}
& \mathrm{v}=\text { volume of the extract solution } \\
& \mathrm{w}=\text { weight of the soil sample } \\
& \mathrm{f}=\text { dilution factor }
\end{aligned}
$$

\section{Determination of Calcium}

Stock solution of calcium standard $(1000 \mathrm{mg} / \mathrm{l})$ was prepared by dissolving $2.4973 \mathrm{~g}$ of dry $\mathrm{CaCO}_{3}$ in $200 \mathrm{ml}$ of distilled water containing $5 \mathrm{ml}$ of concentrated $\mathrm{HCl}$. The solution was heated to drive out $\mathrm{CO}_{2}$ and after cooling it was made up to $1000 \mathrm{ml}$. The stock was diluted to produce working standards of concentration range of $1-100 \mathrm{mg} / 1$.

The AAS was set at the operating wavelength of calcium. The standards and sample were aspirated into the flame as was with potassium and from the calibration curve constructed the concentration of calcium was obtained.

\section{Determination of Sodium}

Stock solution of sodium standard $(100 \mathrm{mg} / \mathrm{l})$ was prepared by dissolving $0.2542 \mathrm{~g}$ of dry $\mathrm{NaCl}$ in distilled water and was made up to $1000 \mathrm{ml}$. The stock solution was diluted to obtain produce working standards of concentration range of $1-100 \mathrm{mg} / \mathrm{l}$.

The standards and sample solution were aspirated into the flame after selecting the operating wavelength of sodium. From the constructed calibration curve the concentration of sodium was determined.

\section{Reagents}

\section{Determination of Phosphates}

Molybdate-Vanadate solution: $25 \mathrm{~g}$ ammonium paramolybdate was dissolved in $500 \mathrm{ml}$ of distilled water. $1.25 \mathrm{~g}$ of ammonium vanadate was dissolved in $500 \mathrm{ml}$ of $1 \mathrm{M}$ nitric acid. Equal volumes of this were mixed thoroughly.

Extracting solution: $0.7 \mathrm{ml}$ of concentrated $\mathrm{H}_{2} \mathrm{SO}_{4}$ and $8.6 \mathrm{ml}$ of $\mathrm{HCl}$ were mixed with $800 \mathrm{ml}$ distilled water, in a $1000 \mathrm{ml}$ volumetric flask and made to mark then mixed thoroughly. 
Stock solution: $1000 \mathrm{mg} / \mathrm{l}$ of phosphate standard was prepared by dissolving $2.198 \mathrm{~g}$ of potassium dihydrogen phosphate in $250 \mathrm{ml}$ of extracting solution in $500 \mathrm{ml}$ volumetric flask then was topped to mark with the extracting solution.

Working solution $(100 \mathrm{mg} / \mathrm{l}): 50 \mathrm{ml}$ of $1000 \mu \mathrm{g} / \mathrm{ml}$ stock solution was measured in a $500 \mathrm{ml}$ volumetric flask then made the volume with the extracting solution

Standards: $0,10,20,30,40,50,60,70$ and $80 \mathrm{ml}$ of working solution was measured, put into $100 \mathrm{ml}$ volumetric flask then, topped with distilled water.

\section{Methods}

$10 \mathrm{~g}$ of dry soil was weighed into clean $100 \mathrm{ml}$ plastic bottles. $50 \mathrm{ml}$ of extracting solution was added then shaken for 60 minutes. The samples were filtered through a whatman No. 42 to get the filtrate. The blank was included. $4 \mathrm{ml}$ of extract and blank was measured into a boiling tube, $1 \mathrm{ml}$-distilled water and $1 \mathrm{ml}$ of molybdate - vanadate added. Mixture was allowed to stand for 20 minutes then was analyzed using UV/Visible spectrophotometer at the operating wavelength of phosphates ${ }^{8}$.

\section{Determination of Nitrates}

Nitrate was extracted in $0.5 \mathrm{M} \mathrm{K}_{2} \mathrm{SO}_{4}$ solution. Using $4 \mathrm{M}$ sodium hydroxide and $5 \%$ salicylic acid, the yellow color was developed and analysis done on UV-VIS spectrophotometer at operating wavelength of nitrates 8 .

\section{Reagents}

Sodium hydroxide 4M: $80 \mathrm{~g}$ of $\mathrm{NaOH}$ pellets were dissolved $500 \mathrm{ml}$ of distilled water

Salicylic acid, 5\%: $2.5 \mathrm{~g}$ of salicylic acid was dissolved in $47.5 \mathrm{ml}$ of sulphuric acid. This solution was made one day before use.

Extracting solution: $50 \mathrm{~g}$ of $\mathrm{K}_{2} \mathrm{SO}_{4}$ was weighed and dissolved in $500 \mathrm{ml}$ distilled water

Nitrates stock solution $(100 \mathrm{mg} / \mathrm{l}): 0.7221 \mathrm{~g}$ of $\mathrm{KNO}_{3}$ was diluted in $100 \mathrm{ml}$ of distilled water. Working solution (10 mg/l): $10 \mathrm{ml}$ of $100 \mathrm{mg} / \mathrm{l}$ will be diluted with water $100 \mathrm{ml}$ volumetric flasks.

Standards: $0,1,2,3,4,5 \mathrm{ml}$ of $10 \mathrm{mg} / 1$ working solution were measured into $50 \mathrm{ml}$ volumetric flasks. These contain $0,2,4,6,8$ and $10 \mathrm{mg} / \mathrm{l}$. This was filled to the mark with $0.5 \mathrm{M} \mathrm{K}_{2} \mathrm{SO}_{4}{ }^{8}$.

\section{Method}

$5 \mathrm{~g}$ of oven dried soil was weighed into a clean $100 \mathrm{ml}$ plastic bottle. $50 \mathrm{ml}$ of $0.5 \mathrm{M} \mathrm{K}_{2} \mathrm{SO}_{4}$ extracting solution was added and shaken for 1 hour. The mixture was filtered through whatman filter paper. $0.5 \mathrm{ml}$ of the sample extract, blanks and the standard series $\mathrm{K}_{2} \mathrm{SO}_{4}$ was transferred into marked test tubes. $10 \mathrm{ml}$ of salicylic acid was added to each test tube and mixed well then stood for 30 minutes. $10 \mathrm{ml}$ of $4 \mathrm{M}$ sodium hydroxide was added, mixed well then left for 1 hour for the yellow color to develop ${ }^{8}$.

\section{Determination Of Micronutrients}

\section{Preparation of Samples for Zinc, copper, iron and lead analysis}

A stock solution of $\mathrm{Zn}(100 \mathrm{mg} / \mathrm{l})$ standard was prepared by dissolving $0.4398 \mathrm{~g}$ of $\mathrm{ZnSO}_{4} .7 \mathrm{H}_{2} \mathrm{O}$ in distilled water and diluted to $1000 \mathrm{ml}$. The stock was diluted to obtain working standards of range of $0-5 \mathrm{mg} / \mathrm{l}$. The sample solution and standards were aspirated in the flame. The calibration curve was used to determine the concentration in ppm of zinc.

$$
\text { Calculations: } \mathrm{Cu}, \mathrm{Fe}, \mathrm{Pb}, \mathrm{Zn}(\mathrm{mg} / \mathrm{Kg})=\frac{(\mathrm{a}-\mathrm{b}) \times \mathrm{V} \times \mathrm{f} \times 1000}{1000 \times \mathrm{w}}
$$

Where: $\mathrm{a}=$ concentration of $\mathrm{Cu}, \mathrm{Fe}, \mathrm{Pb}, \mathrm{Zn}$ in the sample extract

$\mathrm{b}=$ concentration of element in the blank extract

$\mathrm{v}=$ volume of the extract solution

$\mathrm{w}=$ weight of the soil sample

$\mathrm{f}=$ dilution factor

\section{Determination of Copper}

A stock solution of $\mathrm{Cu}$ standard $(100 \mathrm{mg} / \mathrm{l})$ was prepared by dissolving $0.3930 \mathrm{~g}$ of $\mathrm{CuSO}_{4} .5 \mathrm{H}_{2} \mathrm{O}$ in distilled water then diluted to $1000 \mathrm{ml}$. An intermediate of $10 \mathrm{mg} / 1$ was prepared then diluted further to produce a working range of $0-5.0 \mathrm{mg} / \mathrm{l}$. The AAS was set at the operating wavelength of copper and the sample solution and standards aspirated in the flame. From the calibration graph constructed the concentration of the sample were obtained. 


\section{Determination of Iron}

A stock solution of Fe standard $(100 \mathrm{mg} / \mathrm{l})$ was prepared by dissolving $0.1 \mathrm{~g}$ of clean untarnished iron in $10 \mathrm{ml}$ of warm $10 \% \mathrm{H}_{2} \mathrm{SO}_{4}$. After cooling it was diluted to $1000 \mathrm{ml}$

The stock solution was diluted to obtain a working range of $0-20 \mathrm{mg} / \mathrm{l}$. The AAS was set at the operating wavelength of iron. From the calibration graph constructed the concentration of the sample was obtain.

\section{Determination of soil pH}

$10 \mathrm{~g}$ of the soil sample was placed in long beakers and $20 \mathrm{ml}$ of de-ionized distilled water added. The suspension was stirred for 30 minutes and left to stand for 1 hour. The $\mathrm{pH}$ meter was calibrated by buffers of $\mathrm{pH}$ 4 and $\mathrm{pH}$ 7. The $\mathrm{pH}$ was measured by carefully immersing the combined electrode into the clear supernatant solution $^{8}$.

\section{Results And Discussion}

The following calibration curves were obtained after the analysis of the nutrients.

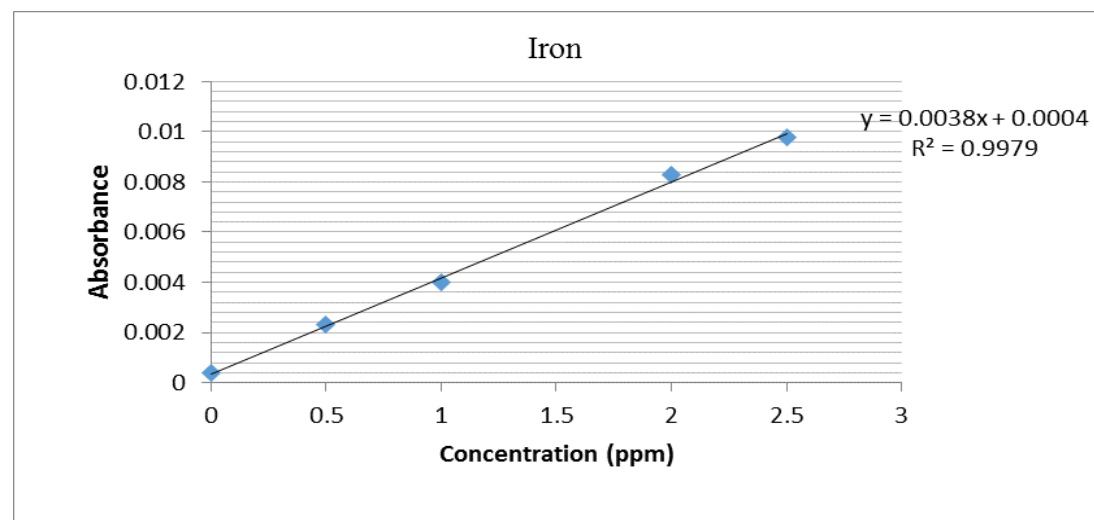

Fig 1: Calibration curve for iron standards

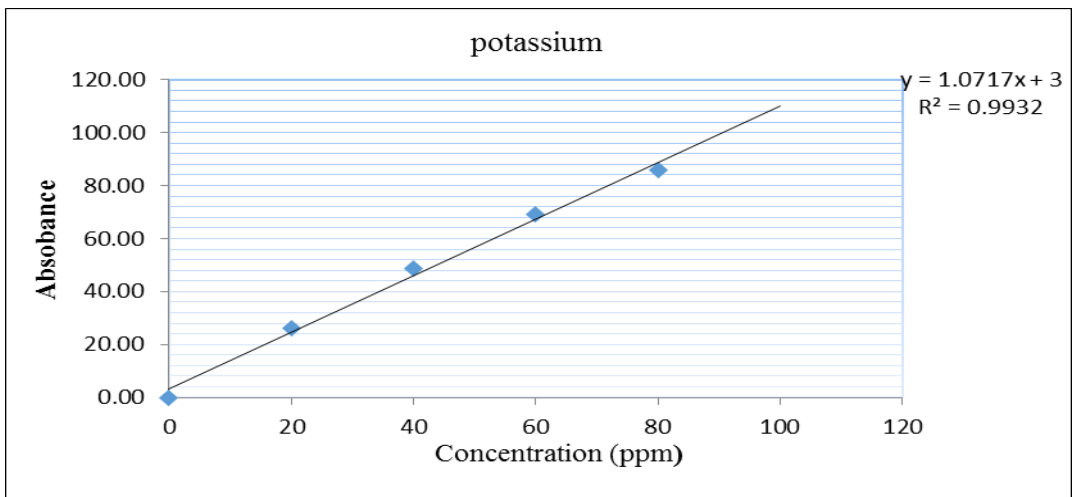

Fig 2: Calibration curve for potassium standards

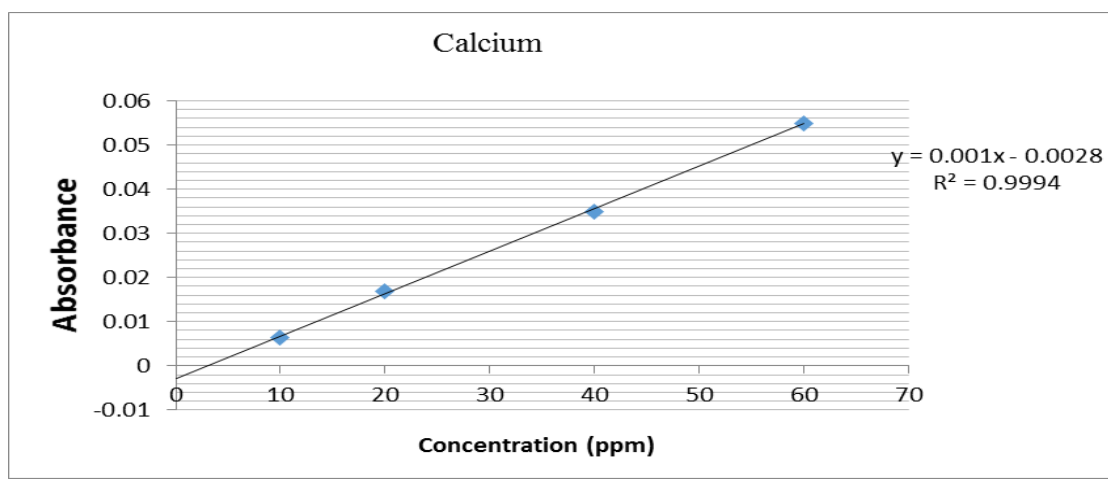

Fig 3: Calibration curve for calcium standard 


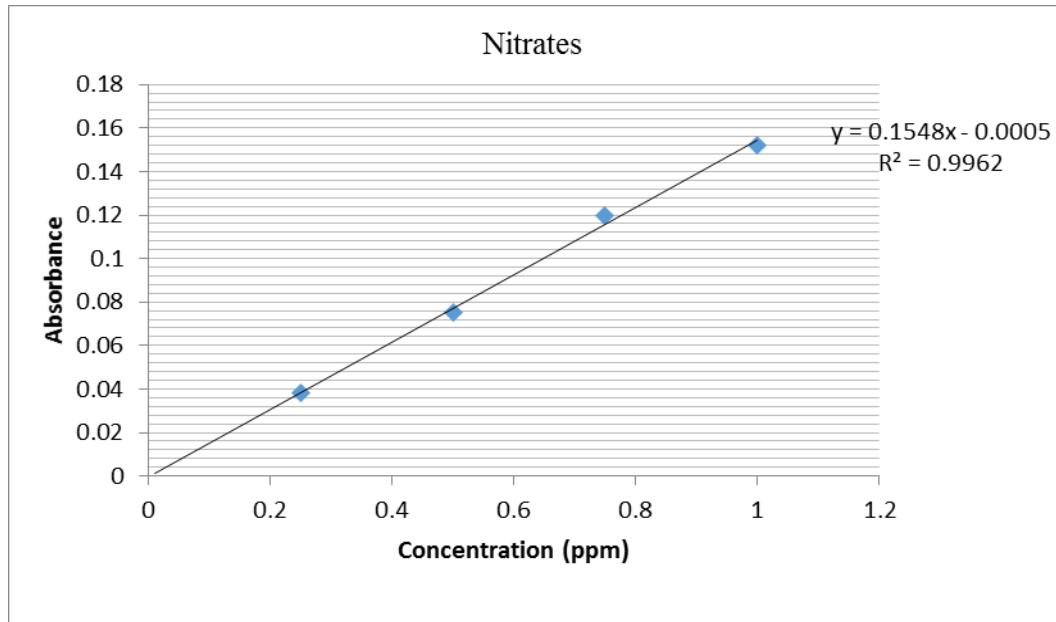

Fig 4: Calibration curve for nitrate standards

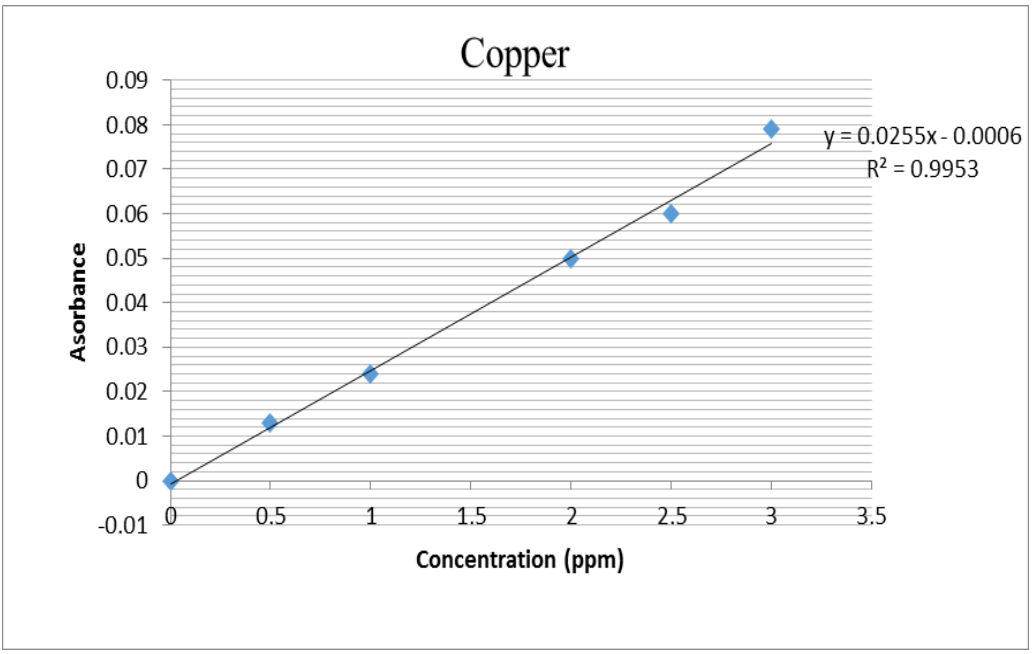

Fig 5: Calibration curve for copper standards

VIII. Discussion

All the measurements were further expressed in $\mathrm{mg} / \mathrm{kg}$ using the equation below Calculations: $\mathrm{K}, \mathrm{Na}, \mathrm{PO}_{4}{ }^{3-}, \mathrm{Cu}, \mathrm{Fe}, \mathrm{Zn}(\mathrm{mg} / \mathrm{Kg})=(\underline{\mathrm{a}-\mathrm{b})} \times \mathrm{V} \times \mathrm{f} \times 1000$

$1000 \times \mathrm{W}$

Where: $\mathrm{a}=$ concentration of $\mathrm{Cu}, \mathrm{Fe}, \mathrm{Pb}, \mathrm{Zn}$ in the sample extract

$\mathrm{b}=$ concentration of element in the blank extract

$\mathrm{v}=$ volume of the extract solution

$\mathrm{w}=$ weight of the soil sample

$\mathrm{f}=$ dilution factor

Tables 1 and 2 indicate the results obtained from the farms in $\mathrm{mg} / \mathrm{kg}(\mathrm{n}=3)$

\begin{tabular}{|l|l|l|l|l|l|}
\hline Sample & $\mathrm{K}$ & $\mathrm{Na}$ & $\mathrm{Ca}$ & $\mathrm{NO}_{3}$ & $\mathrm{PO}_{4}{ }^{3}$ \\
\hline $\mathrm{A}$ & $98 \pm 0.241$ & $194 \pm 0.789$ & $755 \pm 2.36$ & $39 \pm 0.588$ & $105 \pm 1.29$ \\
\hline $\mathrm{B}$ & $39 \pm 1.45$ & $99 \pm 1.87$ & $374 \pm 0.456$ & $104 \pm 3.69$ & $93 \pm 3.25$ \\
\hline $\mathrm{C}$ & $163 \pm 0.36$ & $353 \pm 2.14$ & $235 \pm 1.23$ & $88 \pm 2.35$ & $99 \pm 2.64$ \\
\hline $\mathrm{D}$ & $114 \pm 3.65$ & $305 \pm 1.69$ & $448 \pm 0.895$ & $96 \pm 0.145$ & $93 \pm 0.632$ \\
\hline $\mathrm{E}$ & $140 \pm 1.47$ & $253 \pm 0.987$ & $891 \pm 1.49$ & $30 \pm 1.11$ & $111 \pm 2.88$ \\
\hline
\end{tabular}

Table 1: Macronutrients in $\mathrm{mg} / \mathrm{kg}$ 


\begin{tabular}{|c|c|c|c|}
\hline Sample & $\mathrm{Zn}$ & $\mathrm{Cu}$ & $\mathrm{Fe}$ \\
\hline $\mathrm{A}$ & $20 \pm 1.23$ & $3 \pm 0.041$ & $189 \pm 3.69$ \\
\hline $\mathrm{B}$ & $3 \pm 0.036$ & $0.435 \pm 0.025$ & $144 \pm 0.756$ \\
\hline $\mathrm{C}$ & $8 \pm 0.014$ & $11 \pm 0.021$ & $380 \pm 2.97$ \\
\hline $\mathrm{D}$ & $24 \pm 0.561$ & $1 \pm 0.032$ & $636 \pm 1.25$ \\
\hline $\mathrm{E}$ & $6 \pm 0.078$ & $2 \pm 0.056$ & $381 \pm 1.99$ \\
\hline
\end{tabular}

Table 2: Micronutrients in $\mathrm{mg} / \mathrm{kg}$

Table 3 below gives the $\mathrm{pH}$ measurements obtained from the soil samples.

\begin{tabular}{|l|l|l|l|l|l|}
\hline Sample & A & B & C & D & E \\
\hline $\mathrm{pH}$ & 5.45 & 5.49 & 5.46 & 5.52 & 5.52 \\
\hline \multicolumn{5}{c}{ Table 3: $\mathrm{pH}$ Readings }
\end{tabular}

Chart 1 and 2 below represent graphically the amount of nutrients in each sample

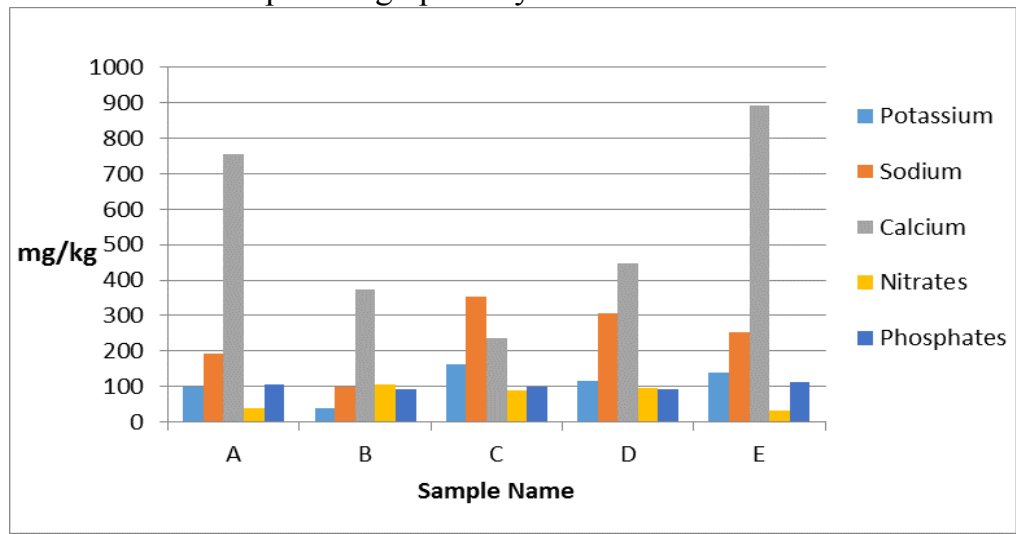

Chart: 1 Macronutrient in $\mathrm{mg} / \mathrm{kg}$

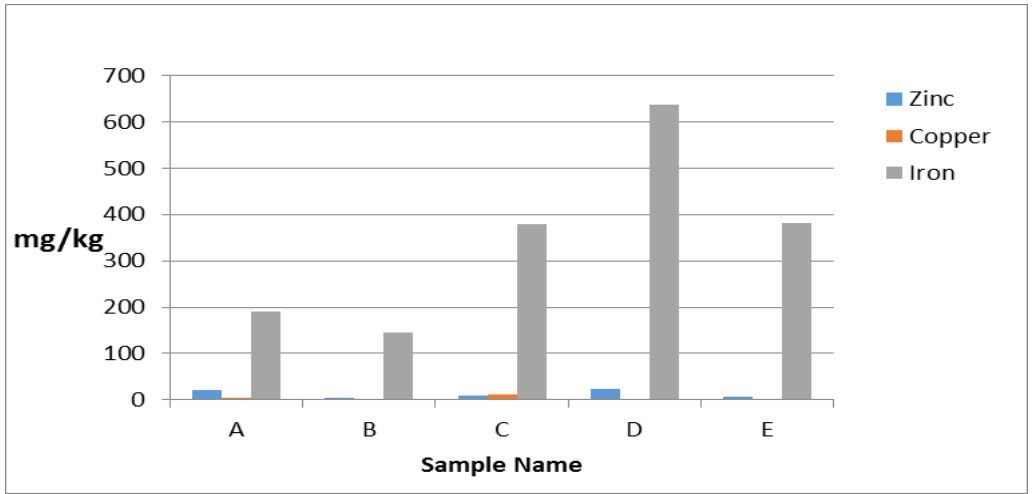

Chart 2: Micronutrients in $\mathrm{mg} / \mathrm{kg}$

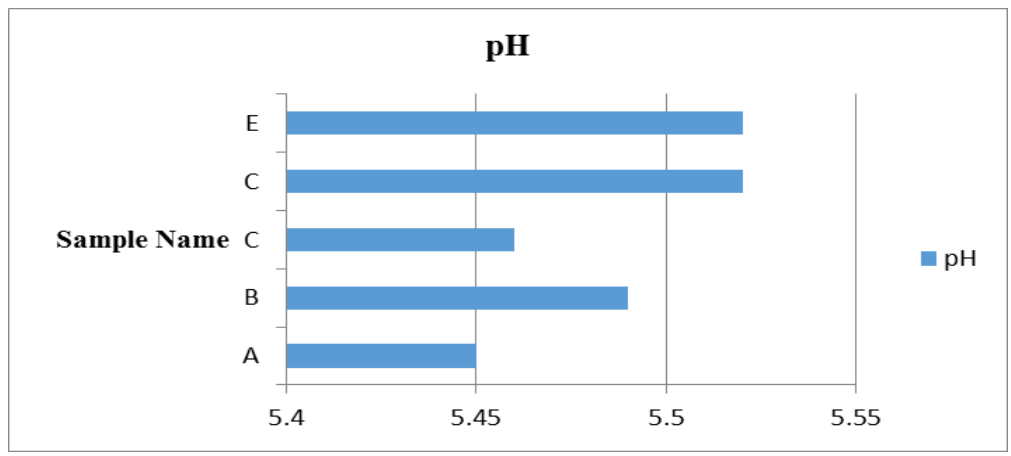

Chart 3: pH levels 
Table 4 indicates recommended macronutrient levels in $\mathrm{mg} / \mathrm{kg}$ as per Kenya Agricultural Research Institute (KARI).

Table 4: Recommended macronutrient levels in $\mathrm{mg} / \mathrm{kg}$

\begin{tabular}{|l|l|l|l|l|}
\hline $\mathrm{PO}_{4}{ }^{3-}$ & $\mathrm{NO}_{3}{ }^{-}$ & $\mathrm{K}$ & $\mathrm{Na}$ & $\mathrm{Ca}$ \\
\hline $2000-5000$ & & $1-100$ & $20-250$ & $2-400$ \\
\hline
\end{tabular}

Table 5 gives a summary indicating the macronutrients contained in each sample whether above, below or within the appropriate levels.

Table 5: Summary of macronutrients in each sample

\begin{tabular}{|l|l|l|l|}
\hline NUTRIENT & $\begin{array}{l}\text { SAMPLE } \\
\text { BELOW }\end{array}$ & $\begin{array}{l}\text { SAMPLE } \\
\text { WITHIN }\end{array}$ & $\begin{array}{l}\text { SAMPLE } \\
\text { ABOVE }\end{array}$ \\
\hline $\mathrm{PO}_{4}{ }^{3-}$ & ALL & - & - \\
\hline $\mathrm{NO}_{3}{ }^{-}$ & ALL & - & - \\
\hline $\mathrm{K}$ & - & A,B & C,D \& E \\
\hline $\mathrm{Na}$ & - & A, B \& E & C \&D \\
\hline $\mathrm{Ca}$ & & B \& C & A, D \& E \\
\hline
\end{tabular}

From Table 5, it is evident that phosphates and nitrates which are very important nutrients are low and below the recommended levels. These two nutrients are primary macronutrients and their availability is paramount for proper crop development. This may be attributed to the failure of application of fertilizer on a regular basis. Potassium, sodium and calcium were available in all samples and some samples surpassed the required levels. Calcium was the most abundant macronutrient in all the farms with exception of farm $\mathrm{C}$ which had sodium as the most abundant. Farm B had relatively lower levels of macronutrients compared to the other farms as shown in Chart 1. The level of macronutrients as observed in Chart 1 from the most abundant to the least abundant was $\mathrm{Ca}>\mathrm{Na}>\mathrm{K}>\mathrm{PO}_{4}{ }^{3-}>\mathrm{NO}_{3}^{-}$.

Micronutrients are trace elements and are utilized in smaller quantities than macronutrients. This is evidenced with the lower concentration values obtained from all the samples as shown in Table 2 compared to the high levels of the macronutrients in Table 1.

Iron was the most abundant of all the micronutrients while copper was the least as shown in Chart 2. Zinc which is involved in enzyme activation had its highest concentration in sample D. For iron, sample A and B were within the recommended levels, samples C, D and E were slightly above the standards. The concentration trend of micronutrients from the most abundant to the least was $\mathrm{Fe}>\mathrm{Zn}>\mathrm{Cu}$

Recommended $\mathrm{pH}$ levels for normal plant growth lie within 5.3 - 6.8 units. All the soil samples were acidic and within the recommended range. The highest $\mathrm{pH}$ was with sample $\mathrm{D}$ and $\mathrm{E}$ at 5.59 while the lowest was sample A with 5.45 as shown in chart 3 . Since the $\mathrm{pH}$ was below 7 this indicated the soils were slightly acidic.

\section{Conclusion}

From the findings of this study it is evident that the levels of phosphates and nitrates were below the required KARI standards. Concentrations of the all the micronutrients under study were within the required levels for normal plant growth. This shows that low phosphate and nitrate content in the soils is a contributor to the low sugarcane yields experienced in the area.

\section{Acknowledgements}

[1]. Kenya Sugar Authority year book of statistics 1999

[2]. Thomas et al, 1967

[3]. O.B Harry and N. C Brady, The Nature and Properties of Soils ; 7th ed 1969, pp 20-33

[4]. C.T Simpson, E Whittemore and W Henderson, Soil. Long man Handbook in Agriculture; 2nd ed, 1981, pp54

[5]. R.I. Donahue, R. W. Miller and J. C Shickluna, Introduction to Soil and Plant Growth, 5th ed, Library of Congress, New York, 1983, pp23

[6]. S. E. Allen, Chemical Analysis of Ecological Material, Blackwell Scientific Publication. Second Edition, 1999, pp 119-155

[7]. Cater M. R (1993). Soil Sampling and Methods of Analysis, 3rd edition. Canadian Soc. Soil sci. Lewis publishers, USA. p 143

[8]. Economic Survey 2001, Kenya National Bureau of Statistics

[9]. Okalebo J.R, Keneth W. Gathua and Paul L. Woomer (2002). Laboratory methods of soil and plant analysis: working manual 2nd edition, p28-40

[10]. Kenya sugar Research Foundation (KESREF) Annual report 2003, Land and water use. 